\title{
RECENZJA - TOMAŠ KOCOUREK, OMEZENI VLASTNICKEHO PRAVA K POZEMKŮM VE PROSPĚCH OCHRANY ŽIVOTNIHO PROSTŘEDI, NAKLADATELSTVI LEGES, PRAHA 2012, S. 278
}

\section{REVIEW - TOMAŠ KOCOUREK, OMEZENI VLASTNICKEHO PRAVA K POZEMKŮM VE PROSPĚCH OCHRANY ŽIVOTNIHO PROSTŘEDI, NAKLADATELSTVI LEGES, PRAHA 2012, PP. 278}

\section{STRESZCZENIE}

Celem opracowania jest charakterystyka i ocena publikacji naukowej: Tomaš Kocourek, Omezeni vlastnickeho prava $k$ pozemkům

* Prof. dr hab., Instytut Nauk Prawnych PAN. 
ve prospěch ochrany životniho prostředi, Nakladatelstvi Leges, Praha 2012, s. 278.

\section{Słowa kluczowe} dowiska.

Prawo własności, ograniczenie prawa własności, ochrona śro-

\section{ABSTRACT}

Objective of the review is to characterize and evaluate monograph: Tomaš Kocourek, Omezeni vlastnickeho prava $k$ pozemkim ve prospěch ochrany životniho prostředi, Nakladatelstvi Leges, Praha 2012, pp. 278.

\section{Keywords}

Right of property, limitation of property rights, environmental protection.

Opublikowaną w praskim wydawnictwie „Leges” monografię Tomaša Kocourka, poświęconą ograniczeniom prawa własności do gruntów na rzecz ochrony środowiska, bez wahania zaliczam do znaczących osiągnięć czeskiej doktryny prawa środowiska. Autor podjął temat niezwykle skomplikowany, przedstawił go z imponującym wykorzystaniem doktryny nie tylko czeskiej, ale i innych państw, w szczególności francuskiej i niemieckiej, uwzględnił orzecznictwo Europejskiego Trybunału Praw Człowieka, przeprowadził dogłębną analizę czeskich rozwiązań prawnych i zakończył przekonywającą syntezą.

Autor ujął swe rozważania w sześciu rozdziałach:

1. Założenia teoretyczne i konstytucyjnoprawne.

2. Typologia ingerencji w prawo własności i rekompensat za szkody spowodowane jego ograniczeniem.

3. Granice wykonywania prawa własności i jego ograniczenia nałożone przekrojowymi instrumentami ochrony środowiska. 
4. Granice wykonywania prawa własności i jego ograniczenia w poszczególnych ustawach odnoszących się do komponentów środowiska.

5. Aspekty procesowe wyznaczania granic wykonywania prawa własności i jego ograniczeń.

6. Ochrona osób trzecich przed niekorzystnymi skutkami wyznaczania granic prawa własności i jego ograniczeń.

Pracę kończy zgrabne podsumowanie, trzystronicowe streszczenie francuskie oraz wykazy wykorzystanej literatury i orzecznictwa.

Przystępując do recenzowania monografii, ujmuję recenzję jako sprawozdawczą. Jest to zrozumiałe; żaden nie-Czech nie jest $\mathrm{w}$ stanie sporządzić recenzji krytyczno-polemicznej dzieła, którego przedmiotem jest prawo czeskie. Myślę jednak, że rozwiązania czeskie z dziedziny m.in. prawa konstytucyjnego oraz oparte na nich rozważania autora, wzbogacone o analizy szczegółowe, są tak interesujące, a także inspirujące, że w pełni zasługują na zaprezentowanie ich czytelnikowi polskiemu, co czynię.

Zacznę od zamieszczonych w rozdziale 1 rozważań Tomaša Kocourka nad prawem własności i prawem do środowiska w ujęciu teoretycznym i konstytucyjnym. Przypomnę, że na czeski porządek konstytucyjny składają się:

1) Konstytucja Republiki Czeskiej - Ustava ${ }^{1}$ Česke republiky - uchwalona 16 grudnia 1992 r.,

2) Karta Podstawowych Praw i Wolności - Listina zakladnich prav a svobod - przyjęta jeszcze w okresie istnienia Federacji Czecho-Słowackiej 9 stycznia 1991 r. i 16 grudnia 1992 r. uznana za część składową porządku konstytucyjnego Republiki Czeskiej.

Podstawową normą konstytucyjną dotyczącą własności jest art. 11 Karty, który - dla ułatwienia śledzenia wywodów autora recenzowanej monografii - przytoczę in extenso $\mathrm{w}$ tłumaczeniu własnym:

1 Czytelnikowi polskiemu należy się wyjaśnienie, że czeska ustava to polska „konstytucja”, natomiast polska „ustawa” to czeski zakon, a polski „kodeks" to czeski zakonik. 
Art. 11. (1) Każdy ma prawo do własności mienia. Prawo własności wszystkich właścicieli ma taką samą ustawową treść i ochronę. Gwarantuje się dziedziczenie.

(2) Ustawa stanowi, jakie mienie niezbędne do zabezpieczenia potrzeb całego społeczeństwa, rozwoju gospodarki narodowej i interesu publicznego może być tylko własnością państwa, gminy lub określonych osób prawnych; ustawa może także stanowić, że określone rzeczy mogą być tylko własnością obywateli lub osób prawnych z siedzibą w Czeskiej i Słowackiej Republice Federacyjnej.

(3) Własność zobowiązuje. Nie może być nadużyta na szkodę praw innych podmiotów albo sprzecznie z interesami powszechnymi chronionymi ustawą. Jej wykonywanie nie może uszkadzać ludzkiego zdrowia, przyrody i środowiska ponad miarę ustanowioną ustawą.

(4) Wywłaszczenie lub przymusowe ograniczenie prawa własności jest możliwe w interesie publicznym, na podstawie ustawy i za odszkodowaniem.

(5) Podatki i opłaty można nakładać tylko na podstawie ustawy.

Tomaš Kocourek sięga do Konstytucji Republiki Weimarskiej z 1919 r., która w art. 153 ust. 3 stanowiła, że własność zobowiązuje, a jej wykonywanie ma służyć także dobru powszechnemu. Ta norma została przejęta przez zachodnioniemiecką Grundgesetz z 1949 r. w art. 14 ust. 2 i tym właśnie inspirował się czeski ustrojodawca, włączając do art. 11 ust. 3 Karty słowa o tym, że własność zobowiązuje, a jej wykonywanie nie może być nadużyte. Prawo własności nie wykazuje już typowych znamion zaliczanych do tzw. status negativus, lecz zostało wzbogacone o nakładane przez państwo nakazy i zakazy. Własność przestała być pojmowana wyłącznie jako instrument realizacji indywidualnych interesów, lecz stała się także instrumentem realizacji celów społeczeństwa. Między tymi dwoma grupami interesów dochodzi często do napięć i konfliktów, które rozwiązuje nie tylko ustawodawca, ale przy ocenianiu konkretnych sporów także administracja publiczna i sądy (s. 18-19).

Autor zwraca uwagę, że w nowoczesnym państwie prawnym tylko niektóre prawa i wolności mają charakter absolutny, 2/2013 tj. są nieograniczone i nieograniczalne. Większość z nich, a na- 
leży do nich także ochrona własności, ma charakter względny. Karta Podstawowych Praw i Wolności w art. 4 ust. 2 pozwala na to, aby ustawa stanowiła granice podstawowych praw i wolności na warunkach określonych Kartą (s. 19).

Płodne naukowo są wywody autora o dwóch grupach ograniczeń własności w art. 11 Karty. Pierwsza przedstawia granice wykonywania prawa własności (meze vykonu vlastnickeho pra$v a)$. Ustrojodawca wyznaczył je w art. 11 ust. 3 Karty, stanowiąc, że własność pełni funkcję socjalną (zobowiązuje). Powszechną granicą wykonywania prawa własności jest zastrzeżenie, że nie może to prowadzić do uszkodzenia zdrowia ludzkiego, przyrody i środowiska ponad miarę wyznaczoną ustawą. Ustawodawca może przyjąć środki wyznaczające granice wykonywania prawa własności, których celem jest ochrona interesów powszechnych, a do nich należy także ochrona środowiska. Za wyznaczenie granic wykonywania prawa własności nie należy się żadna rekompensata. Owszem, państwo w swej szczodrości, wykorzystując swobodę, jaką dysponuje w działalności legislacyjnej, może przyznać roszczenie o wyrównanie szkody spowodowanej ustanowieniem niektórych granic wykonywania prawa własności, ale nie ma takiego obowiązku.

Drugą grupę ograniczeń prawa własności przedstawiają tzw. prawa ograniczeń (prava omezeni), do których odnosi się art. 11 ust. 4 Karty. Podczas gdy granice prawa własności oddziałują na jego treść od wewnątrz (chodzi o wewnętrzne granice wykonywania prawa własności), ograniczenia przedstawiają zewnętrzną ingerencję $\mathrm{w}$ treść prawa własności. Ograniczenia prawa własności wychodzą ponad ramy wewnętrznych granic wykonywania tego prawa. Z tego względu ustrojodawca ustanowił w art. 11 ust. 4 Karty surowsze warunki nakładania ograniczeń prawa własności. Ograniczyć takie prawo można tylko $\mathrm{w}$ interesie publicznym, na podstawie ustawy i za odszkodowaniem. Takie same warunki odnoszą się do wywłaszczenia.

Konstytucyjność ograniczenia prawa własności i obowiązek przyznania odszkodowania za ograniczenie należy odróżniać od siebie. $Z$ metodologicznego punktu widzenia należy najpierw odpowiedzieć na pytanie, czy ingerencję władzy publicznej w prawo własności można ocenić jako ograniczenie 
w rozumieniu art. 11 ust. 4 Karty i czy taka ingerencja spełnia warunki ustanowione Kartą, które odnoszą się do wszelkich ingerencji w konstytucyjnie gwarantowane prawa, tj. czy ma podstawę ustawową, czy była dokonana w interesie publicznym i czy odpowiada wymaganiom proporcjonalności. Jeżeli się potwierdzi, że ingerencja w prawo własności jest jego ograniczeniem, które jest zgodne z konstytucją, to dopiero w drugim etapie trzeba zająć się pytaniem, czy ustawa reguluje roszczenie o naprawienie szkody ${ }^{2}$ powstałej w następstwie ograniczenia prawa własności. Jeżeli roszczenie o naprawienie szkody w ogóle nie jest uregulowane na poziomie ustawowym albo jest uregulowane niedostatecznie, to z uwagi na to, że jest gwarantowane w art. 11 ust. 4 Kary, należy przystąpić do bezpośredniego stosowania tej normy konstytucyjnej. Naprawienie szkody jest $\mathrm{w}$ takim przypadku dokonywane bezpośrednio na podstawie art. 11 ust. 4 Karty. Poszczególne postanowienia Karty są bowiem bezpośrednio obowiązującym prawem i uprawnień w nich uregulowanych można domagać się bezpośrednio z odwołaniem się do postanowień Karty. Tę myśl, kluczową dla całej monografii, autor wpiera orzecznictwem czeskiego sądu konstytucyjnego (s. 20-22).

Przystępując do szczegółowej analizy relacji między ograniczeniami prawa własności a granicami jego wykonywania, au-

2 W prawie czeskim rozróżnia się dwa pojęcia škoda i ujma. Relacje między nimi są objaśniane różnie. W prawie środowiska w odniesieniu do szkody majątkowej używa się zazwyczaj określenia majetkova škoda, ale w odniesieniu do szkody ekologicznej już tylko ekologicka ujma. Pewne światło na to zagadnienie rzuca nowy czeski kodeks cywilny, obowiązujący od 1 stycznia 2014 r. - Zakon č. 89/2012 Sb, občansky zakonik. Wyjaśniam, że czeskie akty prawne powołuje się w ten sposób, że po literze „č” (čislo = numer) następuje pozycja, pod którą akt został opublikowany w oficjalnym zbiorze aktów prawnych (Sbirka zakonů), łamana przez rok pierwotnej publikacji (bez względu na ewentualne późniejsze teksty jednolite) i zakończona literami „Sb.” (skrótowcem oficjalnego zbioru aktów prawnych). Jak wyjaśniają twórcy kodeksu, ujma jako pojęcie zarówno koncepcji kodeksu nadrzędne jest zarówno ujmą na osobie, jak ujmą na prawach, jak wreszcie ujmą na mieniu. Ujma dzieli się na szkodę i niemajątkową ujmę (K. Eliaš, B. Havel, P. Bezouška, D. Šuštrova, Občanske pravo pro každeho. Pohledem /nejen/ tvưrců noveho občanskeho zakoniku, Praha 2013, s. 259). 
tor zauważa, że odnośne postanowienia Karty używają odmiennych określeń, mianowicie w art. 11 ust. 3 jest mowa o interesie powszechnym (obecny zajem), podczas gdy w art. 11 ust. 4 jest mowa o interesie publicznym (veřejny zajem). Zdaniem autora różnica polega na intensywności, ta zaś uwarunkowana jest dziedziną i przedmiotem, których ochrona leży w interesie publicznym bądź powszechnym. Czym bardziej wyjątkowe są dziedziny i przedmioty, tym intensywniejszy jest interes ich ochrony. Intensywność ochrony określonych obiektów wynika z ich właściwości, zwłaszcza jednostkowości, wyjątkowości, wysokim stopniem wymagań ich zachowania, ale z drugiej strony także wyższym stopniem ich zanieczyszczenia czy groźbą pogorszenia stanu funkcji ekologicznych itp. Można przeto powiedzieć, że interesy publiczne przedstawiają kwalifikowaną grupę interesów powszechnych, charakteryzująca się wyższą intensywnością, tj. np. pilnością, pierwszorzędnym znaczeniem lub nieodwracalnością następstw, które miałoby ich naruszenie. Z intensywnością interesu w ochronie obiektów ręka w rękę idzie też intensywność dopuszczalnych ograniczeń prawa własności. Ograniczenia w interesie publicznych mogą być przeto dotkliwsze i poważniejsze niż ograniczenia (czy też granice) prawa własności w interesie powszechnym (s. 26).

Konkluzja autora jest następująca: ograniczenia prawa własności w rozumieniu art. 11 ust. 4 Karty występują wtedy, gdy mają jako następstwo wyłączenie realizacji prawa własności w niektórych jego aspektach albo wprowadzają w niedającym się pominąć (nezanedbatelnym) rozmiarze nierówność między różnymi grupami właścicieli typowo jednakowych lub podobnych gruntów. Tak dotkliwe restrykcje treści prawa własności są dopuszczalne tylko wtedy, kiedy są uzasadnione intensywnym interesem społecznym, dla którego Karta posługuje się oznaczeniem ,interes publiczny”. W odróżnieniu od tego granice wykonywania prawa własności w rozumieniu art. 11 ust. 3 Karty nie prowadzą ani do wyłączenia bądź istotnego ograniczenia realizacji niektórych atrybutów prawa własności, ani nie tworzą nierówności między właścicielami takich samych lub podobnych typów gruntów, ponieważ odnoszą się do wszystkich gruntów wykazujących te cechy. Ponieważ grani- 
ce wykonywania prawa własności przedstawiają o wiele mniej znaczące restrykcje treści prawa własności i w swej istocie formują samą treść tego prawa, wystarczą dla ich uzasadnienia mniej intensywne interesy społeczne. Karta określa je jako „interesy powszechne" (s. 29).

Powstanie roszczenia o naprawienie szkody (narok na nahradu ujmy) według regulacji art. 11 ust. 4 Karty jest, zdaniem autora, uwarunkowane spełnieniem trzech przesłanek jak:

1) ograniczenie prawa własności $w$ następstwie normatywnego aktu prawnego lub aktu indywidualnego administracyjnego lub sądowego; to ograniczenie musi sięgać odpowiedniej intensywności bądź godzić w specjalny wąski krąg osób, aby można je było poddać regulacji art. 11 ust. 4 Karty, podczas gdy przy ustanawianiu granic wykonywania prawa własności nie powstaje roszczenie o odszkodowanie, chyba że ustawy dotyczące komponentów środowiska przyznają takie roszczenie także $\mathrm{w}$ przypadku ingerencji w uprawnienia właścicielskie niesięgające poziomu ograniczenia,

2) powstanie szkody (ujmy), w tym wypadku majątkowej, polegającej na zmniejszeniu wartości mienia albo utracie korzyści bądź utracie wzrostu wartości w przyszłości,

3) związek przyczynowy między ograniczeniem prawa własności a szkodą.

Autor podkreśla, że roszczenie o zrekompensowanie szkody nie jest częścią składową odpowiedzialności prawnej ani sankcją, jest wyrazem ogólnej koncepcji sprawiedliwości (s. 36-38).

Cenne są uwagi autora poświęcone relacji między pojęciami ujma i škoda. Treściowo te pojęcia są bardzo podobne, zwłaszcza co do charakteru (ingerencja w podstawy majątkowe) i komponentów (damnum emergens i lucrum cessans), ale roszczenie o naprawienie szkody ma charakter prywatnoprawny, podczas gdy roszczenie o naprawienie ujmy jest publicznoprawne, ponieważ ograniczenie praw właścicielskich następuje 2/2013 aktem publicznoprawnym (s. 38-39). 
Drugim filarem badanej przez autora problematyki jest pravo na přiznive životni prostredi - prawo do sprzyjającego ${ }^{3}$ środowiska. Nie ma on wątpliwości, że środowisko jest dobrem publicznym. Cechą takich dóbr jest to, że nie można ich pojęciowo, rzeczowo ani prawnie rozłożyć na części i przydzielić jako udziały jednostkom. Z tego wynika, że nie mogą być dystrybuowane między jednostki i jednocześnie nikt nie może być wyłączony z korzystania z tych dóbr. Kwalifikacja środowiska jako dobra publicznego nie stoi na przeszkodzie, aby równocześnie spoglądać na nie jako na prawo podmiotowe (s. 41).

Tak też postąpił ustrojodawca czeski, formułując prawo do środowiska $\mathrm{w}$ znajdującym się $\mathrm{w}$ rozdziale o prawach gospodarczych, społecznych i kulturalnych art. 35 Karty Podstawowych Praw i Wolności, który przytoczę in extenso w tłumaczeniu własnym:

Art. 35. (1) Każdy ma prawo do sprzyjającego środowiska.

(2) Każdy ma prawo do odpowiednio wczesnej i pełnej informacji o stanie środowiska i zasobów przyrodniczych.

(3) Przy wykonywaniu swych praw nikt nie może zagrażać ani uszkadzać środowiska, zasobów przyrodniczych, gatunkowego bogactwa przyrody ani zabytków kultury ponad miarę ustanowioną ustawą.

Powołując się na orzecznictwo czeskiego sądu konstytucyjnego i poglądy wyrażone w piśmiennictwie, Tomaš Kocourek wywodzi, że art. 35 Kary zobowiązuje państwo, aby zapewniło osiągnięcie sprzyjającego stanu środowiska, a więc aby wytworzyło dostateczne mechanizmy zabezpieczające przed szkodli-

3 Tłumaczenie czeskiego terminu přiznive napotyka na poważne trudności. Słownikowo přiznivy to „życzliwy, przychylny, przyjazny, sprzyjający, pomyślny". W piśmiennictwie czeskim odnoszącym się do prawa do środowiska ten termin oddaje się także przymiotnikami „zdrowe, czyste, zrównoważone itp." Zob. H. Müllerova, Aktualni otazky zakotveni lidskeho prava na životni prostředi $v$ mezinarodnim pravu, Acta Universitatis Carolinae, Iuridica 3/2011, s. 43. Myślę, że przekład „sprzyjające” albo „odpowiednie” oddaje sens tego pojęcia. Sam preferuję „sprzyjające”, ku czemu mnie skłania słownikowi przykład priznivy vitr, który już na pewno trzeba tłumaczyć jako „sprzyjający wiatr". 
wymi ingerencjami i aby oddziaływało środkami kontrolnymi i sankcyjnymi w celu realizacji tego zadania. Prawo do sprzyjającego środowiska ma swoją własną normatywną treść, która jest w wysokim stopniu relatywna, wobec czego trzeba je interpretować $\mathrm{z}$ wielu aspektów i zawsze $\mathrm{z}$ uwzględnieniem konkretnej sprawy. Jego treść konkretyzują i bliżej rozwijają ustawy dotyczące komponentów środowiska. Domagać się realizacji tego prawa można wszakże tylko w granicach ustaw, które to prawo wprowadzają (art. 41 ust. 1 Karty). Prawa do sprzyjającego środowiska nie można przeto uznawać za prawo bezpośrednio stosowalne (s. 42).

Podsumowując trwały dorobek orzecznictwa czeskiego sądu konstytucyjnego, autor wywodzi, że w stosunku do praw, których realizacji można domagać się tylko w granicach określonych ustawą, regulacja ustawowa, która je wprowadza, nie musi być w ścisłej relacji proporcjonalności do założonego celu. Zgodne z Konstytucją są nie tylko środki niezbędne w demokratycznej społeczności, jak to jest w odniesieniu do innych praw, których można domagać się bezpośrednio na podstawie Karty. Test konstytucyjności, oznaczany mianem testu racjonalności, przejdzie taka regulacja ustawowa, w której można stwierdzić dążenie do osiągnięcia jakiegoś legitymowanego celu i która to czyni w sposób dający się uznać za rozsądny środek jego osiągnięcia, aczkolwiek nie musi to być koniecznie środek najlepszy, najdogodniejszy, najskuteczniejszy czy najmądrzejszy. Test racjonalności jest koncypowany przede wszystkim dla praw socjalnych, dla których typowe jest, że zakres, w którym można się ich na podstawie ustawy domagać, zależy od ekonomicznej sytuacji społeczności. Jednakże treść prawa do sprzyjającego środowiska nie jest uwarunkowana wielkościami ekonomicznymi. W odróżnieniu od praw socjalnych, które tworzą jakiś katalog nadbudowy (nadstavbovy katalog), sprzyjające środowisko jest przesłanką życia człowieka. Mając na uwadze art. 41 ust. 1 Karty, można dopuścić, aby konstytucyjność ustaw tworzących treść tego prawa była oceniania łagodniej niż klasycznym testem proporcjonalności, ale z drugiej strony ostrzej niż testem 2/2013 racjonalności (s. 42-43). 
Te wywody prowadzą autora do rozważań nad kluczowym dla całej monografii problemem rozwiązywania kolizji między ochroną prawa własności i prawa do sprzyjającego środowiska. Przyjęty przez autora punkt wyjścia jest taki, że stosunki prawne regulowane ustawami o komponentach środowiska, ustawą budowlaną i ustawą o wywłaszczeniu można w płaszczyźnie najogólniejszej określić mianem konfliktu (střet) prawa własności i interesu ochrony środowiska. Stają naprzeciw siebie dwa konstytucyjnie chronione prawa podmiotowe (s. 44).

Nie istnieje, zdaniem autora, hierarchia konstytucyjnie gwarantowanych praw i wolności czy też dóbr publicznych, porządek konstytucyjny obchodzi się z nimi jednakowo. To co prawda nie znaczy, aby miały taką samą wewnętrzną wartość i znaczenie. Ograniczyć podstawowe prawo czy wolność można tylko z powodu innego elementarnego prawa czy wolności. Kolizje między dwoma konstytucyjnie gwarantowanymi prawami rozwiązuje się najczęściej w demokratycznych państwach prawnych przez koncepcję proporcjonalności. Autor zauważa, że test proporcjonalności wywodzi się z orzecznictwa niemieckiego sądu konstytucyjnego. Czeski sąd konstytucyjny wykorzystuje klasyczny trójelementowy test proporcjonalności, którego częściami składowymi są elementy odpowiedniości, potrzeby i stosunkowości, tj. proporcjonalności w znaczeniu węższym (s. 44-45).

Autor zwraca uwagę, że czeski sąd konstytucyjny odnosi się do kolizji istniejących konstytucyjnie gwarantowanych praw, mając na uwadze argumenty empiryczne, systemowe, kontekstowe i sięgające do wartości.

Argument systemowy jest oparty na ocenie położenia rozważanego prawa podstawowego $\mathrm{w}$ systemie wszystkich podstawowych praw i wolności. Podczas gdy prawo własności jest prawem podstawowym, prawo do sprzyjającego środowiska jest „tylko” prawem trzeciej generacji i można się go domagać tylko w granicach określonych ustawą. Nie można wszakże przeoczyć, że według judykatury Europejskiego Trybunału Praw Człowieka niektóre aspekty prawa do sprzyjającego środowiska są częścią składową prawa respektowania prywatności życia rodzinnego lub prawa do niezakłóconego używania mienia. Do tego jesz- 
cze trzeba dodać, że art. 35 ust. 3 Karty limituje wykonywanie praw (w tym i prawa własności) właśnie na rzecz ochrony środowiska. W ten sposób z punktu widzenia systemowego prawo trzeciej generacji znacząco zbliża się do poziomu prawa podstawowego pierwszej generacji.

Argument sięgający do wartości dotyczy oceny pozostających w kolizji praw podstawowych wobec akceptowanej hierarchii wartości. Ochrona prawa własności w tej hierarchii znajduje się na jednym z pierwszych miejsc, co jest uzasadnione przede wszystkim niedobrymi doświadczeniami z epoki socjalizmu. Zmianie stosunków społecznych towarzyszyła restauracja własności prywatnej, jej ochrony i przywrócenie majątku określonym grupom ludzi. Wskazane fakty formują znaczące miejsce ochrony prawa własności w hierarchii wartości. Ochrona własności jest jednym z podstawowych postulatów (znamion) demokratycznego i prawnego państwa. Z drugiej strony społeczne znaczenie prawa do sprzyjającego środowiska wykazuje $\mathrm{w}$ ostatnich dziesięcioleciach potężny wzrost. Jedna z podstawowych zasad ochrony środowiska jest oznaczana jako zasada najwyższej wartości, według której środowisko jest podstawową przesłanką życia człowieka. Jest porównywalne z takimi wartościami, jakimi są życie, zdrowie i wolność. Ocena pod kątem jakości środowiska znacznie się w społeczeństwie rozszerza i zmienia spojrzenie na inne tradycyjne wartości. Europejski Trybunał Praw Człowieka wyraził pogląd, że ani interesom ekonomicznym, ani niektórym prawom podstawowym, wśród nich ochronie własności, nie powinno się przyznawać pierwszeństwa na szkodę środowiska. Autor przychyla się do stanowiska, że ochrona środowiska powinna mieć absolutne pierwszeństwo zawsze, kiedy grozi nieodwracalne uszkodzenie jego komponentów (s. 48).

Po krótkiej wzmiance o argumentach empirycznych i kontekstowych autor konkluduje, że pomimo iż środowisko jest dobrem publicznym, trzeba przy ocenie jego kolizji z podstawowymi prawami i wolnościami stosować tradycyjny test proporcjonalności, obejmujący nakaz optymalizacji. Sprzyjające środowisko należy w związku z tym ujmować jako konstytucyj2/2013 nie gwarantowane prawo, a nie jako dobro publiczne. Chodzi 
mianowicie o to, że podczas gdy podmiotowych praw publicznych można się domagać na drodze sądowej, w tym przypadku w granicach określonych ustawa (art. 41 Karty), to realizacji dobra publicznego sądowo domagać się nie można. Z tego autor wywodzi prymat pojmowania sprzyjającego środowiska jako prawa podmiotowego, konstytucyjnie chronionego (s. 49).

W rozdziale 1 recenzowanej monografii Tomaš Kocourek położył wzorcowo solidny fundament pod rozważania szczegółowe będące przedmiotem rozdziałów 3-6. Przed przejściem do nich w rozdziale 2 autor zajął się narzędziami analizy, przedstawiając interesujące typologie ingerencji w prawo własności. Jako jedno z kryteriów przyjął uprawnienia właścicielskie, którego dotykają ingerencje. Na jego podstawie rozróżnił (s. 50):

- ingerencje w ius disponendi, np. ustawowe prawo pierwokupu nieruchomości,

- ingerencje w ius utendi - większość ingerencji w prawo własności,

- ingerencje w ius abutendi - związane z poprzednimi, ponieważ sensem ochrony środowiska jest zapobiec zniszczeniu przedmiotu ochrony; w odniesieniu do gruntów raczej należy mówić o uszkodzeniu.

W ustawach z zakresu ochrony środowiska nie występują natomiast ingerencje $\mathrm{w}$ inne aspekty prawa własności typu ius possidendi czy ius dereliquendi.

Ingerencje $\mathrm{w}$ prawo własności występują $\mathrm{w}$ postaci ustanowienia zakazów (obowiązek typu omittere), ustanowienia warunków ograniczających, ustanowienia nakazu czynienia czegoś (obowiązek typu facere) lub obowiązku znoszenia czegoś (obowiązek typu pati). Jedynym typem obowiązku, którego nie spotkamy w przypadku ingerencji w prawo własności, jest obowiązek typu dare.

Stanowienie zakazów, nakazów i ograniczeń należy do podstawowych instrumentów prawnych ochrony środowiska i przedstawia typowy przejaw administracyjnoprawnej metody regulacji stosunków społecznych.

Ze względu na kryterium formalnego źródła ingerencji w prawo własności autor rozróżnia następujące typy ingerencji polegające na ograniczeniu lub zakazie działania (s. 51-52): 
- wprowadzone bezpośrednio ustawą, niewymagające żadnego innego aktu,

- wprowadzone bezpośrednio ustawą, przy czym inne akty wyznaczają przestrzenny zakres zakazu lub ograniczenia,

- uregulowane w ustawie z dopuszczeniem wyjątków,

- uregulowane w ustawie, wymagające sprawdzenia $\mathrm{w}$ akcie indywidualnym, czy konkretny zamiar lub działanie mieszczą się w ich zakresie,

- ustanowione w ustawie i bardziej szczegółowo uregulowane w akcie administracyjnym o charakterze ogólnym $^{4}$,

- nakładane indywidualnym aktem administracyjnym,

- nakładane aktem administracyjnym o charakterze ogólnym,

- nakładane innymi aktami,

- niewyrażone w ustawie, ale inne ustawy bądź akty normatywne wymagają zajęcia wiążącego stanowiska lub udzielenia zgody na określone działanie,

- wynikające z umowy.

Intensywność ingerencji w prawo własności znacznie się różni, a to właśnie $\mathrm{w}$ zależności od tego, w jakim akcie ma swe źródło ograniczenie lub zakaz działania. Generalnym założeniem jest to, że ingerencja w prawo własności ustanowiona ustawą lub aktem abstrakcyjnym przedstawia granice wykonywania prawa własności w znaczeniu art. 11 ust. 3 Karty,

4 W czeskim języku prawnym - opatreni obecne povahy. Jest to pojęcie zdefiniowane w czeskiej ustawie o postępowaniu administracyjnym - zakon $\check{c}$. 500/2004 Sb., spravni r̆ad - w § 171 od strony negatywnej: przepisy ustawy procesowej stosują się wtedy, gdy ustawa szczególna upoważnia do wydania opatřeni obecne povahy, które nie jest ani aktem normatywnym, ani decyzją administracyjną. Komentator uznaje taki akt za mieszany, mający cechy zarówno aktu ogólnego, jak i administracyjnego, np. jeżeli jego przedmiot jest konkretnie oznaczony, ale dotyczy nieoznaczonego kręgu adresatów, albo odwrotnie: konkretnie oznaczony adresat lub adresaci i nieoznaczone przedmioty (zob. P. Průcha, Spravni řad s poznamkami a judikaturou, Praha 2012, s. 429-430). Dodam, że nowe i nowelizowane ustawy z zakresu szeroko rozumianej ochrony środowiska coraz częściej posługują się formą opatřeni obecne povahy także przy stanowieniu zakazów i ograniczeń. 
podczas gdy ingerencje, które mają formę indywidualnego aktu administracyjnego lub innego aktu z konkretnym przedmiotem, są ograniczeniem prawa własności w znaczeniu art. 11 ust. 4 Karty. Tego założenia nie można jednak absolutyzować ani przeceniać jego wagi. Chodzi raczej o jakąś pomoc, pierwsze przybliżenie prowadzące do nadania kwalifikacji badanej ingerencji w prawo własności.

O ograniczeniu prawa własności chodzi tylko w dwóch typowych przypadkach: właścicielowi gruntu odjęto niektóre z uprawnień właścicielskich albo co najmniej w istotny sposób wywarto na nie wpływ (przypadek materialnego wywłaszczenia); drugim przypadkiem jest mniej intensywna ingerencja w prawo własności - dotyka ona wszakże stosunkowo wąskiej grupy właścicieli, którzy w porównaniu z pozostałymi właścicielami rodzajowo zbieżnych gruntów znajdują się w nierównym położeniu (koncepcja szczególnej ofiary /zvlaštni oběti/ czy też nierównomiernego rozłożenia ciężarów publicznych). Nie jest przy tym decydujące, jaką formalną postać ma ingerencja w prawo własności (s. 52-53).

$\mathrm{Na}$ fundamencie położonym $\mathrm{w}$ rozdziale $1, \mathrm{z}$ zastosowaniem narzędzi analizy rozpracowanych $w$ rozdziale 2 , Tomaš Kocourek wznosi w dwóch kolejnych rozdziałach podstawową konstrukcję, analizując:

w rozdziale 3 przekrojowe (průrezove) instrumenty ochrony środowiska zawarte w ustawach:

- o planowaniu przestrzennym i budownictwie ${ }^{5}$,

- o wywłaszczeniu ${ }^{6}$,

$\mathrm{w}$ rozdziale 4 instrumenty zawarte w ustawach o komponentach środowiska (složkove zakony):

- o ochronie zasobu gruntów rolnych ${ }^{7}$,

- wodnej ${ }^{8}$,

5 Zakon č. 183/2006 Sb., o uzemnim planovani a stavebnim řadu (stavebni zakon).

6 Zakon č. 184/2006 Sb., o odněti nebo omezeni vlastnickeho prava k pozemku nebo ke stavbě (zakon o vyvlastněni).

7 Zakon č. 334/1992 Sb., o ochraně zemědělskeho půdniho fondu.

8 Zakon č. 254/2001 Sb., o vodach a o změně některych zakonů (vodni zakon). 
- o ochronie przyrody i krajobrazu',

- leśnej ${ }^{10}$,

- łowieckiej ${ }^{11}$,

- rybackiej ${ }^{12}$

- uzdrowiskowej ${ }^{13}$,

- o pieczy nad zabytkami ${ }^{14}$.

Przedstawienie wyników badań autora nad dziesięcioma ustawami jest $\mathrm{w}$ ramach recenzji niemożliwe. Zatrzymam się nad metodą. Otóż autor badając zakazy i ograniczenia zamieszczone w poszczególnych ustawach, uwzględniając także akty wykonawcze i kompetencje do wydania aktów administracyjnych, odpowiada na pytania, czy te zakazy i ograniczenia przedstawiają granice wykonywania prawa własności, czy też ograniczenia prawa własności, czy ustawodawca przyznaje odszkodowanie, czy go nie przyznaje, czy przyznanie odszkodowania jest obowiązkiem ustawodawcy, czy wychodzi ponad te obowiązki, czy w razie braku wzmianki o odszkodowaniu możliwe jest i pod jakimi warunkami bezpośrednie zastosowanie art. 11 ust. 4 Karty i dochodzenie odszkodowania wyłącznie na tej postawie.

Sposób podejścia autora do badanych zagadnień zilustruję trzema przykładami z ustawy o pieczy nad zabytkami. Przypomnę, że zgodnie z czeską koncepcją środowiska zabytki wprawdzie nie są pochodzenia przyrodniczego, lecz antropogenicznego, ale uznawane są za komponenty środowiska w rozumieniu prawnym, dlatego ustawa o pieczy nad zabytkami jest zaliczana do prawa środowiska.

9 Zakon č. 114/1992 Sb., o ochraně přirody a krajiny.

10 Zakon č. 289/1995 Sb., o lesich a o změně a doplněni některych zakonů (lesni zakon).

11 Zakon č. 449/2001 Sb., o myslivosti.

12 Zakon č. 99/2004 Sb., o rybnikařstvi, vykonu rybařskeho prava, rybařske straži, ochraně mořskych rybolovnych zdrojů a o změně některych zakonů (zakon o rybařstvi).

13 Zakon č. 164/2001 Sb., o přirodnich lečivych zdrojech, zdrojech přirodnich mineralnich vod, přirodnich lečebnych laznich, lazenskych mistech a o změně některych souvisejich zakonů (lazeňsky zakon).

14 Zakon č. 20/1987 Sb., o statni pamatkove peči. 
Pierwszy przykład dotyczy uznania za zabytek kultury lub narodowy zabytek kultury. Jego właściciel powinien na własny koszt dbać o zachowanie zabytku, utrzymania go w dobrym stanie i ochronę przed zniszczeniem i uszkodzeniem. Może go używać tylko w sposób odpowiadający jego znaczeniu kulturalnemu, wartości pomnikowej i stanowi technicznemu. Te ograniczenia są, zdaniem autora, ograniczeniami prawa własności w rozumieniu art. 11 ust. 4 Karty. Ustawodawca przewidział kilka form rekompensaty za ograniczenia. Jedną z nich jest udzielenie fachowej pomocy i niezbędnych informacji. Jeśli jednak chodzi o odszkodowanie pieniężne, to $\S 16$ ustawy jedynie pozwala przyznać organowi państwowej pieczy nad zabytkami pomoc pieniężną $\mathrm{w}$ trzech sytuacjach: 1) chodzi o szczególnie uzasadniony przypadek, 2) właściciel zabytku nie jest w stanie ponieść z własnych środków kosztów zachowania lub odnowienia zabytku, 3) nadzwyczajny interes społeczny w zachowaniu zabytku. Problem polega na tym, że ustawa nie przyznaje właścicielowi roszczenia o pomoc finansową, pozostawiając jej udzielenie uznaniu organu. Autor idąc śladem wytyczonym przez jedno z orzeczeń sądu konstytucyjnego konkluduje, że właściciel ma jednak roszczenie o rekompensatę, wywodzone bezpośrednio z art. 11 ust. 4 Karty na rzeczywiste i dające się wykazać nakłady. Rekompensata ma postać pomocy finansowej przewidzianej w $\S 16$ ustawy, ale jeżeli ta pomoc nie została udzielona lub nie pokrywa w całości zwiększonych nakładów na pieczę nad zabytkiem, właściciel gruntu zabytkowego może domagać się odszkodowania na podstawie art. 11 ust. 4 Karty (s. 169).

Drugiego przykładu dostarczają rezerwaty kulturowe ( $p a-$ matkove rezervace) i strefy zabytkowe; taką strefą (pamatkowa zona) jest np. teren bitwy pod Sławkowem (niegdyś Austerlitz). Ingerencja $\mathrm{w}$ prawo własności gruntów w rezerwatach kulturowych i strefach zabytkowych polega jedynie na tym, że właściciel gruntu musi uzyskać wiążące stanowisko organu wobec określonych typów działalności (budowa, prace ziemne, umieszczenie lub usunięcie urządzenia itp.). Dopiero w zależności od treści wiążącego stanowiska można dojść do wniosku, czy właściciel jest ograniczony w swym prawie korzystania z gruntu. Trzeba 
dalej zbadać, czy takie ograniczenia są większe niż nieznaczne, gdyż dopiero wtedy można sięgnąć do art. 11 ust. 4 Karty (sama ustawa roszczenia odszkodowawczego nie przyznaje). Zdaniem autora nie można oceniać abstrakcyjnie, czy reżim odnoszący się do gruntów w rezerwatach kulturowych i strefach zabytkowych należy kwalifikować jako ograniczenie prawa własności w rozumieniu art. 11 ust. 4 Karty, potrzebna jest ocena ściśle indywidualna (s. 172).

Wreszcie trzeci przykład to strefy ochronne wyznaczane wokół zabytków, rezerwatów kulturowych i stref zabytkowych. W strefach ochronnych mogą być wprowadzane pewne nieznaczne ograniczenia prawa własności, za które $\S 17$ ust. 4 ustawy przewiduje roszczenie o rekompensatę. Autor ocenia, że nie ma żadnych podstaw do bezpośredniego stosowania art. 11 ust. 4 Karty, co więcej, roszczenia z § 17 ust. 4 ustawy wychodzą ponad ramy Karty, ponieważ powstają także wtedy, gdy ingerencja $\mathrm{w}$ prawo własności nie sięga stopnia jego ograniczenia w znaczeniu art. 11 ust. 4 Karty, skoro ustawa nie stanowi, że przedmiotem odszkodowania jest tylko szkoda większa niż nieznaczna (s. 174).

Solidny fundament teoretyczny i koncepcyjny oraz przemyślane narzędzia badawcze pozwoliły autorowi osadzić na tym fundamencie konstrukcję zasługującą na najwyższe uznanie. Dopełnienie obrazu analizami proceduralnymi w rozdziale 5 oraz zbadaniem instrumentów ochrony osób trzecich w rozdziale 6 pozwalają mi ocenić dzieło Tomaša Kocourka jako wybitne, stanowiące znaczący wkład w teorię prawa środowiska.

Kontakt e-mail:

kpos@umk.pl 